15 sec., the next one being sent simultaneously as a radio signal and as an acoustic signal, the latter by means of a loud speaker oriented in the direction of the harbour. By measuring with a stop watch the time elapsing between the radio signals and the sound signal, the distance is known. To render this practical, the ship is equipped with a special microphone tuned to the note sent by the beacon and the head telephones of the observer can be switched over automatically from the radio set to the microphone.

The apparatus is clearly capable of uses other than providing a 'bee' line course for a ship entering harbour in fog. The transmitter may be swung in azimuth to any bearing to provide a silent zone upon which a ship may navigate at right angles if necessary.

\title{
Researches on Glasshouse Plants
}

\section{$\mathrm{T}$} HE nineteenth annual report (1933) of the Experiment and Research Station established by the Nursery and Market Garden Industries' Development Society, Ltd., at Turner's Hill, Cheshunt, Herts, shows a gratifying co-operation between the glasshouse grower and the scientific worker. The director of the Station, Dr. W. F. Bewley, reports that manurial and variety trials of tomatoes have been prosecuted for some time, and various items of practice, such as planting in trenches, digging in spent hops, chrysanthemum roots and clean straw, have been investigated. A very important experiment relates to heating the soil. This was done by means of hot-water pipes buried in the ground. Circulation of water in the pipes was maintained by means of an electric pump controlled by a soil thermostat. The results show a considerable increase in yield due to the higher temperature of the soil. The use of oil fuel has been investigated through two seasons, and an increased financial return of more than $£ 210$ per acre was obtained as against the use of anthracite fuel. This was due to the uniformity of temperature which was maintained throughout the whole of the day and night. Experiments on cucumbers and lettuce find a place in the report, which also contains, within its 115 pages, detailed results of mycological, entomological and physiological investigations by members of the Station staff.

Many short descriptive and research papers of interest to mycologists and entomologists appear in the report. On p. 39, Mr. P. H. Williams writes on leafy gall of the chrysanthemum, discussing its etiology and methods for control. Dr. W. F. Bewley and Mr. O. B. Orchard have a short note on rose diseases, and Mr. H. G. White describes vegetable diseases, including grey mould (Botrytis rot or wilt) of lettuce, bean wilt, and a disease of rhubarb. The same author also writes on the sterilisation of lettuce seeds. Messrs. O. B. Orchard and W. H. Read describe the control of leaf mould of tomatoes by fumigation with sulphur or quinone. Several virus diseases form the subject of a contribution by Dr. G. C. Ainsworth, and physiological investigations of mosaic disease of the tomato have been prosecuted by Mr. W. H. Read.

Mr. E. R. Speyer contributes articles on the red spider mite, the tomato-moth caterpillar, parasites of the tomato-moth, thrips and millepedes. Mr. O. B. Orchard writes on the control of wireworms and millepedes, and upon the joint destruction of tomato leaf mould and red spider mite, for which a combined insecticide and fungicide has been suggested. The Station continues to propagate and distribute a parasite of the greenhouse white fly.

The report also contains several contributions upon soil conditions and plant growth in glasshouses. Dr. $O$. Owen has investigated the leaching of nitrates and potash from soil used for growing tomatoes. Nitrates are not present in the drainage from heated soil in such large quantities as they occur in unheated soil, whilst the addition of spent hops has the effect of increasing the amount of nitrate in the leachings. The effect of manurial treatment on the nitrogen contents of some market garden crops has also been investigated by Dr. Owen. Mr. B. D. Bolas contributes a paper on the influence of light and temperature on the assimilation rate of seedling tomato plants, whilst Mr. R. Melville has studied the effect of water content of the plant upon assimilation. Some aspects of translocation in the seedling tomato plant are described by Mr. I. W. Selman. Messrs. W. H. Read and $O$. B. Orchard have a paper on plant injury following the burning of sulphur in glasshouses, and Dr. W. F. Bewley and Messrs. Read and Orchard report the results of numerous experiments on conditions which affect the quality of tomatoes.

\section{Heavy Hydrogen and Heavy Water}

A SURVEY of the applications of heavy hydrogen $A$ in research has been published by $H$. S. Taylor (J. Franklin Inst., 218, 1 ; 1934). The method of preparation of pure deuterium oxide by electrolysis is described, with full experimental details, and the properties enumerated. The density is found to be ${ }_{25} D^{25} 1 \cdot 1079$, in contrast to the value $1 \cdot 1056$ found by G. N. Lewis and Macdonald, whilst the freezing point, $+3 \cdot 82^{\circ}$, is in good agreement with that found by the latter experimenters.

Pure heavy water is very hygroscopic, and readily absorbs moisture from the air and from containing vessels. Mass-spectrographic results show that the ratio of deuterium to hydrogen in ordinary rain water is $1: 5000$. The ratio of the isotope of mass $3\left(\mathrm{H}^{3}=\mathrm{T}\right)$ to deuterium (D) in the gas from the electrolysis of the best samples of heavy water is less than $1: 50,000$, and in ordinary water less than $1: 5 \times 10^{8}$.

The equilibrium $\mathrm{H}_{2}+\mathrm{D}_{2} \rightleftharpoons 2 \mathrm{HD}$ is of importance in the study of surface catalysis. Glass, mercury, charcoal, etc., are inactive in promoting the reaction, but active nickel and charcoal oxide induce the change even at the temperature of liquid air, the activities of the surfaces being quite specific. A summary of the results on the biochemistry of heavy water is given. The enzyme catalase is only half as active in 85 per cent deuterium oxide as in ordinary water. Bacteria, as contrasted with protozoa and rotifers, are not killed. Compounds of deuterium other than the oxide are known, and a detailed 
account of the properties of the deuteroammonias, $\mathrm{NDH}_{2}, \mathrm{ND}_{2} \mathrm{H}$ and $\mathrm{ND}_{3}$, is given.

Experiments on the hydrolysis of palmityl chloride and the enzymic hydrolysis of triolein, on the effect of heavy water on the respiration and fermentation of yeast, on xanthin oxidase, and on the cytochromeindophenol oxidase system, as well as on the swelling of gelatin, have been reported by Rideal, Hughes, Yudkin and Kemp (J. Chem. Soc., 1105; 1934). The results with yeast confirm the result found by Pascu that heavy water possesses toxic properties. No effect on the rate of hydrolysis of palmityl chloride or triolein was found, nor on the activity of xanthin oxidase or cytochrome-indophenol oxidase. The effect on the swelling of gelatin on replacing water by heavy water up to 90 per cent deuterium content was inappreciable.

\section{University and Educational Intelligence}

THE handbook of lectures and classes for teachers arranged by the London County Council for the session 1934-35 has recently been issued. Courses are being arranged in most branches of education, and will be given at various centres in London. Copies of the handbook and further information can be obtained from the Education Officer, The County Hall, Westminster Bridge, London, S.E.1.

Dr. H. W. Chase, Chancellor of the University of New York, spoke in his inaugural address on June 13 about the freedom of the individual as a condition of the advance of civilisation-a subject on which confessions of faith have been proclaimed on many occasions of late in American university circles, especially since the advent of the Hitler regime in Germany and the consequent eclipse of Lehrfreiheit. While insisting on the necessity for freedom in universities, Dr. Chase reminded his hearers of their obligation to maintain the scientific temper, especially in the fields of the social sciences, now attracting the labour of so many research workers. The address is reproduced in School and Society of June 23.

The Advanced Studies Committee of the University of Oxford has recently published a collection of abstracts of dissertations for the degree of Ph.D. It is vol. 6 of a series of such abstracts and covers the period October 1932-December 1933. Since the institution of this degree in British universities in 1917 , there has been no little uncertainty and controversy as to what it does and should imply, and its standard in relation to other post-graduate degrees; and the matter was three years ago considered of such importance and general interest that it was selected as one of the subjects for discussion at the Fourth Congress of the Universities of the Empire. These Oxford abstracts are full enough to give in many cases a fair indication of the standard of the candidate's work, their average length being about two thousand words. They are grouped under the faculty headings: physical sciences (27), biological sciences (3), modern history (6), medieval and modern languages (5), theology (2), lit. hum. (1), oriental languages (1) and social studies (1). Several are of wide general interest, notably a study by $\mathrm{D}$. $\mathrm{M}$. Eastwood of Somerville of "The Revival of Pascal in France".

\section{Science News a Century Ago}

\section{British Association at Edinburgh}

The Edinburgh meeting of the British Association was held on September 8-15, 1834. In the Analyst (London) it was stated that a dinner was held on the opening day at 5 p.m., attended by 350 persons, with Sedgwick as chairman. He proposed the health of M. Arago, the Astronomer Royal of France. In reply, "M. Arago dwelt on the advantages that must result from the union of the minds of Europe; he regarded it as the pledge of the peace of the world because intellectual supremacy daily acquires more direct power over the affairs of nations, and when the intellectual rulers are banded in friendship the nations subject to this influence cannot be forced into hostility". These sentiments, we read, produced considerable impression. Following the dinner, the inaugural opening of the meeting took place elsewhere, Sir Thomas Brisbane presiding.

The business of the meeting was dealt with by six sections: (1) Mathematies and Physics; (2) Chemistry and Mineralogy; (3) Geography and Geology; (4) Anatomy and Medicine; (5) Natural History; and (6) Statistics.

The subjects discussed in the Section of Mathematics and Physics ranged from capillary attraction, meteorology, magnetism and optics to engineering. Sir David Brewster described some experiments on reflection from crystals, Rennie submitted a report on hydraulics, and Scott Russell dealt with his observations of the traction of boats in canals. The chair in the Section of Chemistry and Mineralogy was taken by Hope, who was occasionally relieved by Dalton. In this Section there was a discussion on chemical notation, while Daubeny described experiments on thermal waters and the heating power of fuels, and Kemp dealt with the liquefaction of gases. Among those who contributed to the proceedings of the Section of Geology was Agassiz.

The Lord Provost awarded diplomas of the freedom of the City to M. Arago, Dr. John Dalton, and Dr. Robert Brown. Evening lectures were given by Dr. Lardner on Babbage's calculating machine; by Prof. Buckland on fossil reptiles; and by Prof. Whewell on phenomena connected with the tides.

\section{Edinburgh as a Meeting Place}

The secretaries for the Edinburgh meeting were Robison and J. D. Forbes. It was largely due to Forbes that the Association met at Edinburgh. A year previous he had written to Sir Thomas Brisbane and to Murchison advocating the claims of Edinburgh as opposed to those of Dublin, Bristol and Liverpool, and in his letter to Murchison he said : "Then as to Bristol, the idea is a new one. Liverpool was spoken of, but as far as I recollect, not the other, nor do I think it a good position. But putting this out of the question, what I object to is your calling Edinburgh a University town, and therefore that it ought not to follow Cambridge. This is quite a mistake. The University gives no character to Edinburgh, and I fear will give little to the meeting. You must be perfectly aware that it is not an academical place, and that the University has nothing to offer. It has no status, no funds, no power. In short, you must never think of the University when you come here, nor compare it in the remotest degree with Oxford and Cambridge. . . ." 